\title{
INCOMPREHENSIBILITY OF GOD AND THE TRINITARIAN CONTROVERSY OF THE FOURTH CENTURY
}

From the very beginning of Christianity, there were two coexistent and mutually complementary currents: one of them spoke about a close God that had manifested himself in Jesus; the second one told about a transcendent God that exceeded all categories of cognition. That situation was called the dialectic of possibility and impossibility of God's cognition. Our point of departure is a question what was the reason why at a certain moment theologians started to focus on the latter idea. Though the concept of incomprehensibility of God was always present in the Church, but previously accent had been placed on showing that God was close thanks to His Grace and Incarnation. It was in the $4^{\text {th }}$ century when a visible shift in accents occurred. That change did not come from nowhere, but it had its source in the Trinitarian controversy ${ }^{1}$. It turns out that the concept of the Trinity and the idea of God's comprehensibility are closely connected as they arise from the same assumptions. Our goal is to show those assumptions, which are not really theological ${ }^{2}$. We are to present not only the connection between the assumptions and the conclusions, but also

* Dr Karolina Kochańczyk-Bonińska - assistant professor at the Chair of History of Early Christian Greek Literature in the Historical Science Institute at the Historical and Social Science Department of the Cardinal Stefan Wyszyński University in Warsaw; e-mail: k.kochanczyk@uksw.edu. pl; dr Marta Przyszychowska - assistant professor at the Chair of Ancient History in the Historical Science Institute at the Historical and Social Science Department of the Cardinal Stefan Wyszyński University in Warsaw; e-mail: mpsi@interia.pl.

${ }^{1}$ The importance of that change was stressed by Tomasz Stępień, cf. Znany - Nieznany Bóg. Uwagi na temat rozwoju doktryny niepoznawalności Boga u chrześcijańskich autorów od II do VI w. (Known vs. Unknown God. Remarks on Development of the Doctrine of Unknowability of God in Church Fathers - II/VI c. AD), "Hybris" 20 (2013) 83-106.

${ }^{2}$ At this point we do not agree with DelCogliano, who tends to seek only theological sources of the concepts raised by both sides; cf. M. DelCogliano, Basil of Caesarea's Anti-Eunomian Theory of Names: Christian Theology and Late-Antique Philosophy in the Fourth Century Trinitarian Controversy, Supplements to Vigiliae Christianae 103, Leiden - Boston 2010, 19. However, it must be stressed that we do not treat philosophical assumptions as if they were "beings/roots" existing purely and exerting an influence on some people. They are rather ideas and thoughts that were present in a lot of writings not only by philosophers, but also theologians before the Eunomian controversy. As 
that the conclusions drawn by both sides of the conflict (by Eunomius and his opponents) were unavoidable.

\section{EUNOMIUS AND ARIUS}

The conflict with Anomoeans has been usually treated as a stage of the Arian controversy, though the latest studies have already proven that neither "orthodox" nor "Arians" were uniform currents ${ }^{3}$. The differences in so called "parties" seem for us evident so we do think the Eunomian controversy is a rather separate chapter in the history of theology. It is something that should be stressed most emphatically ${ }^{4}$. At the first glance, the problems of Arius and Eunomius are similar: both used interchangeably verbal adjectives $\alpha \dot{\gamma} \varepsilon v \eta \eta \tau \varsigma$

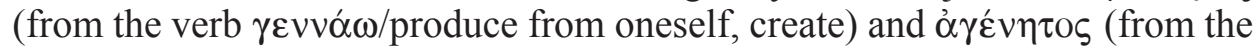
verb $\gamma^{\prime} \gamma \nu 0 \mu \alpha \mathrm{l} / \mathrm{come}$ into being) ${ }^{5}$, which made them recognize the unbegotten Father as the only one without beginning and the only source of any existence. For Arius, that statement was the key to understand the Trinity, but it could be modified depending on a different meaning of those verbal adjectives; Eunomius, on the other hand, did not permit any modifications or interpretations. Richard Hanson claims that Eunomius "took some ideas of what might be called mainstream Arianism and developed them in the eccentric and untypical direction". We are convinced that it was not only possible but also inevitable as his methodology was different ${ }^{7}$. He did not start with a theological deliberation, but with philosophical assumptions. It was his consistency in following some logical assumptions that led Eunomius to conclusions much more radical than those of Arius. Some Fathers called Eunomius a technician not a theo$\operatorname{logian}^{8}$, and his teaching was considered theological rationalism ${ }^{9}$. According to Athanasius of Alexandria, Arius agreed to call the Word God, but only by

such, they can be searched as well in philosophy and in theology, but it does not change the fact that they remain really philosophical.

${ }^{3}$ Cf. L. Ayers, Nicaea and its Legacy: An Approach to Fourth-Century Trinitarian Theology, Oxford 2005, 31-76; DelCogliano, Basil of Caesarea's Anti-Eunomian Theory of Names, p. 3-13.

${ }^{4}$ Although even in 1979 T.A. Kopeček entitled his book about Eunomius and his companions History of Neo-Arianism as he believed that the differences between Arians and Aetius and Eunomius are not strong enough to treat them as a separate phenomenon. We should consider the fact that Arians themselves did not want to be associated with the doctrine of Aetius and Eunomius. Cf. R.P.C. Hanson, The Search for the Christian Doctrine of God: The Arian Controversy 318-381, Grand Rapids 2005, 509.

${ }^{5}$ R.P. Vaggione (Eunomius of Cyzicus and the Nicene Revolution, Oxford 2000, 248) states that Eunomius and other non-Nicenes considered these words equivalent, at least in the context of the divine.

${ }^{6}$ Hanson, The Search for the Christian Doctrine of God, p. 636.

${ }^{7}$ Cf. ibidem, p. $635 \mathrm{n}$.

${ }^{8}$ Cf. J. Daniélou, Introduction, in: Jean Chrysostom, Sur l'incompréhensibilité de Dieu, SCh 28bis, Paris 1970, 13.

${ }^{9}$ Cf. ibidem, p. 26. 
name ${ }^{10}$; Eunomius did not admit such possibility as for him a name denotes an essence. They differed also in their concepts of comprehensibility of God. Richard Vaggione claims: "Whatever Arius actually meant, what both friend and enemy took him to mean was that God is beyond all comprehension, in-

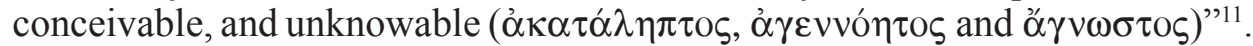
As we will soon see, the point of view of Eunomius was completely different. We think that the reason of such crucial differences is determined by different assumptions. The basis of the Eunomian controversy was philosophy, especially the problem of the origin of names, which is strictly philosophical ${ }^{12}$. Whether Eunomius was a sophistic logician or a genuine philosopher, for our purposes it hardly matters. Anyway, it is really a crucial moment in the history of theology when, we are convinced, experience proved that theology based on specific philosophical concepts inevitably led to heresy.

\section{THE CONCEPT OF EUNOMIUS AND THE CAPPADOCIAN FATHERS}

The main participants in the polemic was Eunomius on one side, and Basil of Caesarea and Gregory of Nyssa on the other ${ }^{13}$. That is why we base our deliberations mostly on their teaching. We can become acquainted with Eunomius' thought from his preserved work Liber apologeticus, published in 1987 by Richard Vaggione in the book entitled Eunomius, The extant works. The complete text of his Apologia apologiae, which was Eunomius' response to Basil's book Adversus Eunomium (which on the other hand was his response to Eunomius' Liber apologeticus), has not been preserved; however, we do have its numerous fragments in the Contra Eunomium by Gregory of Nyssa. The research by R. Vaggione proved that they should be considered reliable ${ }^{14}$.

1. The origin of names. The main assumption that formed the basis for the two opposing systems of Eunomius and the Cappadocian Fathers was the concept of the origin of names ${ }^{15}$. Eunomius was convinced that the names came

${ }^{10} \mathrm{Cf}$. Athanasius Alexandrinus, Orationes contra arianos 1, 6, PG 26, 21-24.

${ }^{11}$ Vaggione, Eunomius of Cyzicus and the Nicene Revolution, p. 64.

${ }^{12}$ It's not our aim to analyse the entire dispute concerning the origin and nature of names. We only want to show how Eunomius introduced his concept of names into the theological debate and what were the consequences of such step as well as the orthodox reaction.

${ }^{13}$ The context of the discussion was carefully referred by M. Cassin in his recent book L'écriture de la controverse chez Grégoire de Nysse. Polémique littéraire et exégèse dans le "Contre Eunome”, Collection des Études Augustiniennes. Série Antiquité 193, Turnhout 2012, 9-48.

${ }^{14}$ Cf. R.P. Vaggione, in: Eunomius, The extant works, text and translation by R.P. Vaggione, Oxford 1987, 89-91.

${ }^{15}$ It is surprising that some authors of the important studies on Eunomius and Basil (cf. A. Orbe, La epinoia. Algunos preliminares históricos de la distinción $\kappa \alpha \tau$ ' Ė $\pi$ ívor $\alpha \nu$ (En torno a la Filosofía de Leoncio Bizantino), Roma 1955; Vaggione, Eunomius of Cyzicus and the Nicene Revolution; 
from God, as (according to Gregory of Nyssa) he says: "God appointed suitable and particular names for the natures"16. It is most probable that he took that belief either directly from Plato or from Neo-Platonists, especially from Proclus, who spoke about a divine origin of names in his commentary to Plato's dialogue Cratylus ${ }^{17}$. It might have referred to the following fragment of Cratylus:

"He [that is Homer] distinguishes between the names by which gods and men call the same things. Do you not think that he gives in those passages great and wonderful information about the correctness of those names? For clearly

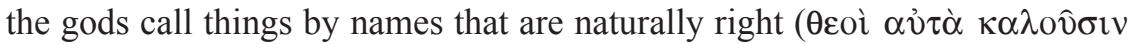

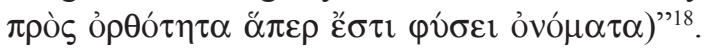

It is characteristic that Gregory of Nyssa himself thought that Eunomius had read that idea in Plato's Cratylus or in some work of Plato's commentators ${ }^{19}$. Though it is not possible to identify precisely the sources of Eunomius's conviction about the divine origin of names ${ }^{20}$, but it can be stated with certitude that he took this assumption from philosophy.

According to the Cappadocian Fathers it is not God who creates names, but God endowed man with the ability of naming things, so man creates names.

A. Radde-Gallwitz, Basil of Caesarea, Gregory of Nyssa, and the Transformation of Divine Simplicity, New York 2009) do not recognize this assumption as a source of different concepts of Eunomius and the Cappadocians. The importance of different concepts of the origin of names was emphasized by such scholars as T. Böhm (Gregors Zusammenfassung der eunomianischen Position im Vergleich zum Ansatz des Eunomius (CE II 1-66), in: Gregory of Nyssa: Contra Eunomium II. An English Version with Supporting Studies. Proceedings of the 10th International Colloquium on Gregory of Nyssa (Olomouc, September 15-18, 2004), ed. L. Karfiková - S. Douglass - J. Zachhuber, Leiden - Boston 2007, 205-216) and L. Karfiková (Der Ursprung der Sprache nach Eunomius und Gregor vor dem Hintergrund der antiken Sprachtheorien (CE II 387-444; 543-553), in: Gregory of Nyssa: Contra Eunomium II, p. 279-306). The point of view of M. DelCogliano (Basil of Caesarea's Anti-Eunomian Theory of Names, p. 43-47) could be seen as stopping half way: he notices the difference in the theory of the origin of names in Eunomius and Basil, but he does not appreciate its importance.

${ }^{16}$ Gregorius Nyssenus, Contra Eunomium II 408, ed. W. Jaeger, GNO 1, Leiden 1960², 345, transl. S.G. Hall, in: Gregory of Nyssa: Contra Eunomium II, p. 151.

${ }^{17}$ Cf. J. Daniélou: Eunome l'Arien et l'exegese neo-platonicienne du Cratyle, REG 69 (1956) 412-432; idem, Gregoire de Nysse at le neo-platonisme de l'ecole d'Athenes, REG 80 (1967) 395401; A. Meredith, The language of God and Human Language, in: Gregory of Nyssa: Contra Eunomium II, p. 250; Vaggione, Eunomius of Cyzicus and the Nicene Revolution, p. 239n.

${ }_{18}$ Plato, Cratylus 391d-e, transl. http://www.hermes-press.com/cratylus2.htm [23 VI 2014]. It is interesting that Plato (as later did Eunomius) combines the divine origin of names with comprehensibility of things: "After all, the simple truth is that anyone who knows a thing's name also knows the thing" (ibidem 435e; cf. ibidem 428d).

${ }^{19}$ Cf. Gregorius Nyssenus, Contra Eunomium II 404, GNO 1, 344.

${ }^{20}$ We should also add Aristotle's logic that influenced Eunomius, together with well-known in his times Neo-Platonism and perhaps some stoics who possibly influenced his thought; cf. Hanson, The Search for the Christian Doctrine of God, p. 630-631; T. Toom, Hilary of Poitiers' De Triniate and the Name(s) of God, VigCh 64 (2010) 9. 
Gregory of Nyssa writes as follows:

"Things have their own nature, whatever it is, it was the linguistic ability

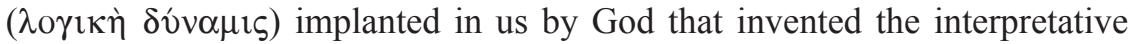
sounds of their names" ${ }^{\prime 21}$.

2. Do names render essences? Those two different assumptions have extremely important ramifications. According to Eunomius names render the very essence of beings, because God knows everything including himself; if he creates names, they necessarily render the nature of things, including the nature of God. He expresses that though in reference to God's Son as follows:

"We call the Son «offspring» ( $\gamma \dot{\varepsilon} v v \eta \mu \alpha)$, therefore, in accordance with the teaching of the Scriptures. We do not understand his essence to be one thing and the meaning of the word which designates it to be something else. Rather, we take it that his substance is the very same as that which is signified by his name, granted that the designation applies properly to the essence

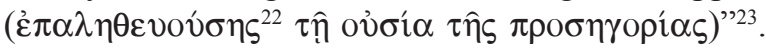

As said before, according to Gregory of Nyssa God gave to all rational beings the ability of reasoning and naming, not names as such ${ }^{24}$. God provided all rational beings with the power of thought and language with the help of which we are able to give names to things. Gregory claims that the names that we give God are either based on our observation of His deeds (cataphatic theology) or a result of negation (apophatic theology). That is the reason why God receives so many different names:

"Since no one title has been discovered to embrace the divine Nature by applying directly to the subject itself, we therefore use many titles, each person in accordance with various interests achieving some particular idea about him, to name the Divinity, as we hunt amid the pluriform variety of terms applying to him for sparks to light up our understanding of the object of our quest"25.

On the contrary, Eunomius teaches that we are able to become acquainted with all beings by knowing their names. That is the consequence of the fact that the names were given by God. Basing on such assumptions Eunomius

${ }^{21}$ Gregorius Nyssenus, Contra Eunomium II 395, GNO 1, 341n., transl. Hall, p. 148.

${ }^{22}$ The verb غ̇ $\pi \alpha \lambda \eta \theta \varepsilon \dot{v} \omega$ means: prove true, substantiate, verify; to be true, genuine; assert truly. It is significant that Gregory of Nyssa uses the same verb to state that the natural notion of names

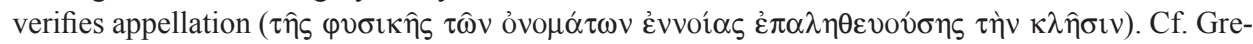
gorius Nyssenus, Contra Eunomium III 1, 95. In his other writing, he claims that nature verifies

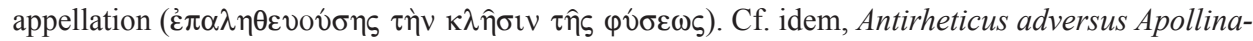
rium, ed. F. Müller, GNO 3/1, Leiden 1958, 199.

${ }^{23}$ Eunomius, Liber apologeticus 12, transl. Vaggione in: The extant works, p. 49.

${ }^{24}$ Cf. Gregorius Nyssenus, Contra Eunomium I 295. 298, GNO 1, 311-312. See also Meredith, The language of God and Human Language, p. 255.

${ }^{25}$ Gregorius Nyssenus, Contra Eunomium II 145, GNO 1, 267, transl. Hall, p. 90. 
claims that he knows God in his essence as unbegotten. Even more, according to Theodoret of Cyrus Eunomius insisted that we knew the essence of God exactly as God knew it himself:

"For he dared to assert such things as not one of the saints ever perceived: that he knows the very essence of God perfectly, and that he has the same knowledge about God as God has about himself! As for those who shared his disfigurement, in their Bacchic frenzy they rushed under his leadership into the same madness, and dared to say outright that they know God as he knows himself!"26.

Then he provokes Basil the Great with the following question: "Do you worship what you know, or what you don't know?"27 In Letter 234, Basil answers by distinguishing between God's essence (ov่ $\sigma^{i} \alpha$ ), which remains beyond our comprehension, and the activities ( of which we predicate of God that he is wise, good, powerful ${ }^{28}$. Even more, the Cappadocian Fathers not only underline that God in his essence could be comprehended neither by any human intellect nor by any angelic one, but they repeat that human intellect cannot become completely acquainted with any created being ${ }^{29}$. A human being is unable to know entirely either himself or the created world: “A creature doesn't know entirely himself or understands the essence of his soul" $"$.

3. Epinoia. The differences in the initial assumptions provoke different conclusions as far as the concept of incomprehensibility of God is concerned. Despite the fact that with regard to the Trinitarian controversy the problems of comprehensibility and nature of God seem crucial, Eunomius and the Cappadocian Fathers differed on a much fundamental level, on the level of the assumptions. We can show this difference while explaining how they understood and defined the term $\dot{\varepsilon} \pi \mathrm{ivoí} \alpha^{31}$.

${ }^{26}$ Theodoretus, Haereticarum fabularum liber quartus, PG 83, 421, transl. Vaggione, in: Eunomius, The extant works, p. 169.

${ }^{27}$ Cf. Basilius Magnus, Epistula 234, ed. Y. Courtonne: Saint Basile, Lettres, texte établi et traduit, vol. 3, Paris 1966, 41-44; Gregorius Nyssenus, Contra Eunomium III 1, 105, ed. W. Jaeger, GNO 2, Leiden $1960^{2}, 39$.

${ }^{28}$ Basilius Magnus, Epistula 234, ed. Courtonne, vol. 3, p. 41-44.

${ }^{29}$ Basil states that man is unable comprehend nature of heaven, cf. Basilius Magnus, Adversus Eunomium III 6, PG 29, 668A-B; we find the same statement in the writings of Gregory of Nyssa, cf. Gregorius Nyssenus, Contra Eunomium II 71, GNO 1, 247.

${ }^{30}$ Gregorius Nyssenus, In Ecclesiasten hom. VII, ed. P. Alexander, GNO 5, Leiden 1962, 416. Cyril of Jerusalem (Catechesis VI 6, PG 33, 548B) also says that man does not know even himself; similarly Basil (Adversus Eunomium III 6, PG 29, 668A).

${ }^{31}$ Cf. Böhm, Gregors Zusammenfassung der eunomianischen Position, p. 213: "Die Differenz ergibt sich m.E. u.a. aus der unterschiedlichen Einschätzung der epinoia: Eunomius wollte offensichtlich verhindern, dass Prädikationen beim Transzendenten von der menschlichen Sprachleistung abhängen, während Gregor den inventiven Charakter der Sprache betont, dann aber eine klare Dif- 
According to the Liddell-Scott Dictionary, $\dot{\varepsilon} \pi$ ıvoí $\alpha$ means thought, thinking on, power of thought, inventiveness; conception, idea; purpose; intelligence and even retrospection. It can have even contradictory meanings as different author are concerned.

Eunomius assumes that names come from God and they are a part of the creation process. As such, they have to correspond to the very essence of things, because if they did not describe essences it would mean that God does not know his creatures. For Eunomius, creating and naming constitute an indivisible unity. The germs of all names were put into man's soul and everyone taught by God is able to read them ${ }^{32}$. According to Gregory of Nyssa Eunomius said:

"It is holy and very fitting to the law of Providence that words are applied.

The Minder of all things by a law of creative design saw fit to sow seeds in our souls" $"$.

That is how Eunomius understands $\varepsilon^{\prime} \pi \imath v o i ́ \alpha$ - according to him it is an ability to read names given by God. things:

Gregory of Nyssa defines ėंıvoía differently - as a way of finding out

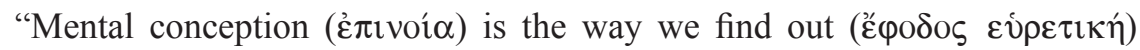
things we do not know, using what is connected and consequent upon our first idea of a subject to discover what lies beyond. Having formed an idea about a matter in hand, we attach the next thing to our initial apprehension by adding new ideas, until we bring our research into the subject to its conclusion" ${ }^{\prime 34}$.

That conclusion does not mean for Gregory cognition of the essence, because the nature of things remains incomprehensible for human beings.

Both sides apply their theory of cognition to God. It would seem that Gregory sees the cause of God's incomprehensibility in his transcendence and infinity, but it is not like that. The reason why God is incomprehensible does not lie in him, in the object, but in the comprehending subject. It is man who comprehends in an imperfect way, and it refers not only to God, but to all other beings, including man himself.

Not only the major part of Gregory's Contra Eunomium refers to his un-

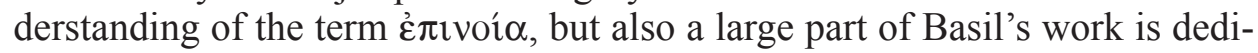
cated to that subject ${ }^{35}$. According to Johannes Zachhuber, the concept of Basil

ferenz von absolutem Bereich und Sprache setzen muss, die ihren Ausdruck in der Unerkennbarkeit und Unsagbarkeit der ousia an und für sich selbst findet".

${ }^{32}$ Cf. Karfiková, Der Ursprung der Sprache nach Eunomius und Gregor, p. 281n.

${ }^{33}$ Gregorius Nyssenus, Contra Eunomium II 546. 548, GNO 1, 267; transl. Hall, p. 386.

${ }^{34}$ Ibidem II 182, GNO 1, 277, transl. Hall, p. 97.

${ }^{35}$ In Adversus Eunomium I 6, 1-2 (ed. B. Sesboüé - G.M. de Durand - L. Doutreleau, vol. 1, SCh 299, Paris 1982, 182) Basil announces that he would like to investigate, what غ̇ंıvoí $\alpha$ as such is. 
is quite convoluted ${ }^{36}$. What we can state for sure is that Basil connects the term $\varepsilon \pi \imath v o i ́ \alpha$ with an intellectual analysis of comprehended things ${ }^{37}$, with a cognition that leads us to find out an inner structure of beings. The sources of such concept can be identified as a philosophical idea that a being exists as one in its essence, but as many in $\dot{\varepsilon} \pi \mathrm{t} v \mathrm{oi}^{38}$. Such concept can be proved by the image of

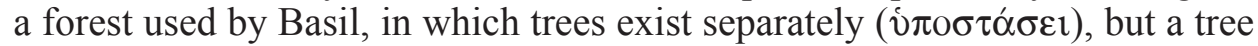

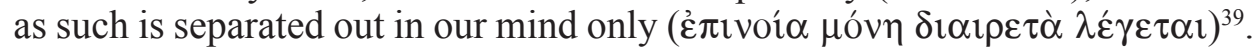
That comparison could be perfectly referred to God, because He exists as one in his substance, but we give him many names, although none of those names render his essence.

Scholars find in Basil's concept an influence of Origen, who with regard to the term $\dot{\varepsilon} \pi$ ivoí $\alpha$ tried to combine the absolute unity of God with the multiplicity of names that describe $\mathrm{Him}^{40}$.

Gregory of Nyssa and Basil differ in their understanding of $\dot{\pi} \pi \mathrm{\imath} v o i \alpha$, but their fundamental assumptions are similar and different from the concepts of Eunomius. According to the Cappadocian Fathers, $\dot{\varepsilon} \pi$ lvoí $\alpha$ is connected to an analytical work of human mind, which allows us to better understand the reality. According to Eunomius, it is a cognition of an essence of things thanks to the germs of names that were put inside us by God.

We tried to show in our paper that the problem of comprehensibility of God appears in the Trinitarian controversy in the $4^{\text {th }}$ century in close connection with the teaching on the Trinity. Eunomius' idea that the essence of God might be comprehended arises from his assumptions. Assuming that names as given by God render the very essence of things and make things comprehensible, it is not possible to consider the divine persons equal and it is necessary to consider God completely comprehensible. Gregory of Nyssa and Basil polemicized with both Eunomius' conclusions: that the divine persons are unequal and that God is incomprehensible because they had different concept of the nature and origin of names ${ }^{41}$.

We are convinced that the Eunomian controversy was crucial not only for the history of theology, but an idea of incomprehensibility, which developed

\footnotetext{
${ }^{36}$ Cf. J. Zachhuber, Christological Titles - conceptually aplied? (CE II, 294-358), in: Gregory of Nyssa: Contra Eunomium II, p. 263n.

${ }^{37}$ Cf. Basilius Magnus, Adversus Eunomium I 6, 44-51, SCh 299, 186.

${ }^{38}$ Cf. Zachhuber, Christological Titles - conceptually aplied?, p. 264.

${ }^{39}$ Cf. Basilius Magnus, Adversus Eunomium I 6, 25, SCh 299, 184.

${ }^{40} \mathrm{Cf}$. Orbe, La epinoia, 36.

${ }^{41}$ The belief that names are unseparately connected with nature of things is, however, represented by Hilary in his De Trinitate. T. Toom (Hilary of Poitiers' De Trinitate and the Name(s) of God, p. 1) states: "While the Cappadocians, countering Heteroousians, eventually demonstrated that naturalist understanding of naming did not work for Christian theology, Hilary still assumed that it did".
} 
in a close relationship with the Trinitarian dispute, had a great influence on the development of apophatic and mistic theology. But that issue could be a subject of separate research.

\section{NIEPOZNAWALNOŚĆ BOGA A SPORY TRYNITARNE IV WIEKU}

\section{(Streszczenie)}

Chociaż koncepcja niepoznawalności Boga zawsze była w Kościele obecna, to w pierwszych wiekach bardziej istotne było ukazanie Boga bliskiego dzięki łasce i wcieleniu. W IV w. wyraźnie widać zmianę w akcentach i roli przyznawanej niepoznawalności Boga przez Ojców. Nie wzięło się to znikąd, ale było ściśle powiązane z kontrowersją eunomiańską, która jest nie tyle częścią polemiki ariańskiej, co osobnym rozdziałem w historii teologii. Wykazujemy w artykule, że podstawą różnic między Aecjuszem i Eunomiuszem z jednej strony a Ojcami Kapadockimi z drugiej były przyjęte przez nich filozoficzne założenia. Zarówno koncepcja osób boskich jak i zagadnienie poznawalności Boga wynikają z przekonania o pochodzeniu nazw: Eunomiusz wierzył, że nazwy zostały stworzone przez Boga, natomiast Ojcowie Kapadoccy utrzymywali, że to człowiek nadaje rzeczom nazwy. Różne założenia doprowadziły ich do różnych wniosków: Eunomiusz uważał, że nazwy oddają istotę rzeczy; Ojcowie, wręcz przeciwnie, byli przekonani, że człowiek nie jest w stanie poznać rzeczywistości, nawet siebie samego. Obie strony zastosowały swoje założenia do możliwości poznania Boga, co nieuchronnie doprowadziło do dwóch rozbieżnych koncepcji: Eunomiusz uznał istotę Boga za całkowicie poznawalną, ojcowie - za całkowicie niepoznawalna.

Key words: incomprehensibility of God, trinitarian controversy of the $4^{\text {th }}$ century, Eunomius.

Słowa kluczowe: niepoznawalność Boga, spory trynitarne IV wieku, Eunomiusz. 
